Original Research Paper

\title{
The Evolution of Women's Political Participation in Various Public Offices in Jordan
}

\author{
Amal Mohummad Ali El Kharouf and Mohummad Al-Jribia \\ Gender and Women Studies, Jordan University, Jordan, Al-Thoria Center for Studies, Jordan
}

Article history

Received: 22-07-2015

Revised: 19-09-2016

Accepted: 30-12-2016

Corresponding Author:

Gender and Women Studies, Jordan University, Jordan, Al Thoria Center for Studies, Jordan

Email: a.alkharouf2002@gmail.com

\begin{abstract}
The study aimed at identifying the evolution of political participation of Jordanian women by monitoring their effective participation during the past decades in the State's legislative and executive authorities. It also aimed at tracing milestones taken towards women's quota law and motives that urge women to run for elections and factors that affect their winning. The study concluded that Jordan worked to include women's issues within the priorities for action and development. Jordanian women made great strides towards their appropriate roles in political life. Women were appointed deputy Prime Minister, Minister of Planning and International Cooperation, Minister of Culture, Minister of Social Development and others, but women were not entrusted with "sovereign" ministries. The percentage of women's representation in the House of Representatives developed rapidly, rising from (1.3\%) in (1993) with one woman deputy to $(12.0 \%)$ in (2013) after the amendment of the electoral law. The number of women Senators increased to nine in the council formed in (2013) which is an indication of the political leadership desire to support women's political participation. A progress has been made; nevertheless women's representation in the Parliament is still under the world average (22\%). Women got satisfactory results in the (2013) municipal elections by winning (29\%) of the seats. The total number of women judges in (2012) was (250) judges. The study pointed out factors that helped women gain seats in the House of Representatives such as: (Women's quota), tribal support, woman's strong personality and previous experiences.
\end{abstract}

Keywords: Jordanian Women, Political Participation, Elections, Jordan, Women's Quota, Tribal Support

\section{Introduction}

The world has witnessed in recent decades a growing interest in women's rights and status in society. Local, regional and international conferences were held and aimed first: To identify obstacles that prevented women's full participation in all political, economic and social spheres and second: To develop future action plans to which governments, non-governmental organizations and the international community commit to implement. At the forefront of such events were conferences held on women in Mexico (1985), Copenhagen (1970), Nairobi (1975) and Beijing (1995) (UNIFEM, 2007a; 2007b:37).

The worldwide call for better conditions for women was linked to basic concepts such as democracy, human rights, development and modernization. These regional and international efforts had important, even if indirect, implications on Women's status. Although they did not bring women to the desired level in most countries of the world, they led to promotion of scientific studies and research that assess women's status in each country, in all fields and sectors and pointed out obstacles facing women.

This movement also contributed to women's awareness of their reality and rights and urged the organization of institutional women's action, albeit to varying degrees, from one country to another. It also encouraged the exchange of expertise and experiences among women in various fields, including the political sphere. The movement urged governments to reconsider their positions regarding women, especially after the United Nations adopted, since 1990, in their reports on development, a new indicator to measure development rates, which is the indicator of women's political participation (Eyadat, 2007: 8, 50-52). 
Political participation is identified as: "The process by which the individual plays a role in political and social life and shall have the opportunity to participate in setting community's general objectives as well as best means to achieve and accomplish these goals" (Othman, 2004: 1).

Women's presence levels in political councils reflect the social and political culture in Arab societies. They also reflect - and to some extent - the vision of the political community, or at least

a part of this community, for these rights, that tends to reduce women's political rights to voting which means dealing with women only as a voice in the voting process and as having numerical strength in the arena of political competition.

The prevailing political culture in many Arab societies and other societies confiscate women's right to exercise political life fully and effectively, which represents one of many factors that hinder women from proving their political efficiency.

In fact, the phenomenon of women's limited political participation is the outcome of many interacting and overlapping factors at the general community level, whether political, economic, social or cultural. Most of the developing countries and Arab societies share these factors, some of which are due to legal reasons, where legislation does not include the principle of equality and political rights might be reserved to men.

The legislation might include the right of nomination and election and yet these paragraphs remain unapplied in whole or in part. Some of these factors are related to cultural patterns which devote stereotypes of women and their role in society, supported by misconceptions about the position of religion regarding women. Other factors are related to the widespread of illiteracy of all kinds in developing societies, especially among females and some are related to the prevailing economic conditions in developing countries, which throw a greater burden on women, especially in light of the challenges of globalization, social transformation, economic and political implications. There are other factors that lead to wasting women's energies and blocking their efforts from the development processes in their communities and political participation that are linked to social and economic participation (Othman, 2004).

Political participation is one of the basic principles which must be fortified in the State and is considered one of the principles that describe democratic systems that are based on citizenship and equality in rights and responsibilities. Some consider that political participation is a practical expression of the voluntary social contract as in it the individual is born as an equal member in the State's body to which he belongs. Unfortunately what realty sometimes ignores is equality and thus eliminates participation (Shbar, 1999, p74).

The individual's political participation is affected by his acquired civil and political knowledge through different sources as visual, read, written media channels, political seminars and electoral campaigns. The higher the civil and political knowledge is increased and diverse the stronger one's participation will be. The individual's political participation is also affected by the political and social system. Liberal systems are open and enhance individuals' desire to participate in politics. Closed system controlled by traditions increase frustration and indifference in individuals (Milbrath, 1965).

As for the Jordanian experience, the country has consistently - under the guidance of His Majesty King Abdullah II Ibn Al Hussein-supported women's integration in public life, through integrated programs directed towards the review of legislation and identifying obstacles and barriers which prevent their participation and building their capacities enabling them to carry out their roles and occupy their proper place and in order to implement these visions, the government has worked to integrate women's issues in the government's agenda, based on the royal visions and texts and the spirit of the Jordanian constitution which emphasizes equality and explicitly refers to the inadmissibility of discrimination. Jordanian women made great strides towards their appropriate roles and getting their full rights in society.

Hereunder, we shall address the evolution of women's participation in different public positions in Jordan as a member of the National Advisory Council, in the executive authority (Minister, Deputy Prime Minister), legislative (member of Parliament, member of the municipal councils and also as a judge) and the steps taken to set women's quota law and then women's motivations to run for elections and finally factors that affect women's winning in elections.

We will use the quantitative and content's analysis approaches, through returning to the database of the Parliament and Senate Councils and the Cabinet and Parliament Councils, to identify the reality of women's participation in elections in the various Councils and to identify the progress of women's participation in public positions.

Also will be reviewing and analyzing a number of literatures (Jribia, 2012; El Kharouf and Al Alkhozai, 2013; the UNIFEM, 2008; MI, 2010; MI, 2002...etc.) to identify the motives of women's participation in elections from a side and the effecting factors in the Victory of women in elections and to know the progress of the idea of women's quota used in various positions (Parliament, municipalities).

\section{Study's Objectives:}

- To identify the evolution of the reality of Jordanian women in the State authorities (executive, legislative and Senate) since 1970 until 2015

- To identify women's quota and its role in women's empowerment in political life 
- To identify motives for women's participation in elections

- To identify the reality of women's participation in parliamentary elections

- To identify factors affecting women's victory in elections

\section{Methodology}

The descriptive and qualitative methodology was used in line with the study's objectives with reference to available data base in the Senate, House of Representatives and Prime Ministry in addition to related published studies in scientific journals.

\section{Previous Studies}

The study of El Kharouf and Al Hosain (2010) "The Experience of Jordanian Women Candidates in Parliamentary Elections in 2007." aimed at identifying economic, social, cultural, demographic, political and legislative factors which affect women's winning in the parliamentary and municipal elections, identifying the use of media and communication channels in the electoral campaign and media's support for women candidates in elections. The study's results indicated that with regard to economic factors affecting the winning of candidates for the House of Representatives, women received support from their husbands, friends and political parties. The study indicated that there were personal and cultural factors which affected women's winning in the parliamentary elections such as women's strength of character, self-confidence and enjoyment of significant political knowledge. Then came the effect of social factors, mainly related to tribal views, customs and traditions, as well as social factors that had an impact particularly with regard to women's support to other women, women's participation in social events and volunteer activities. The most influential legislative factors were: The quota system, then the number of voters in each electoral district, the number of voters in a given district and then came the impact of the parliamentary election's law/division of electoral districts, number of candidates in the same circle, the law of the parliamentary election/number of electoral districts and the number of candidates in a given district, the number of votes in a district, synchronization of the voters registration in the parliamentary and municipal elections, time between the parliamentary and municipal elections and the law of parties and the mechanism of calculating the quota.

The study El Kharouf and Nabulsi (2011) "Reality and Needs of Jordanian Women in Municipal Councils" aimed at identifying the situation of women members in the municipal councils in Jordan, identifying the needs of women members in the municipal councils in Jordan. The study concluded that women members in municipal councils shared special characteristics as they were from different specialties of higher education. Some among them enjoyed prior experience in the field of volunteer work, had the ability to communicate with Municipal Council members and the community, desire to contribute, take responsibility and cooperate to serve the community. Weakness points were lack of experience in political issues and relevant laws, marginalization of some of the chairpersons and members of women's role in the municipality, in addition to their poor financial situation. Their available opportunities were represented by the quota system, tribal weight, profiting from previous experiences of women members in the council and good social relations with the local community. They were challenged by absence of a headquarters for women members which hindered their continuous presence, women's numerous responsibilities, one-vote system, nepotism in addition to weak participation of women in the various committees. Their needs were in the field of managerial and technical skills and enhancing legislative knowledge of Jordanian Constitution and the system of formal bids and functions of the municipal council's committees.

The study of Majeed et al. (2011) "Political Awareness and Political Participation of Rural Women in Jordan, Survey Study" examined political awareness and political participation of rural women as well as the correlation between them. The study recommended giving serious attention and support to rural women and their various activities by government officials and institutions on the local level and enhancing the role of civil societies and the national mass media in developing cultural and political awareness programs.

Al Sharah and Gwanmeh (2011) "The Feminist Quota in the Jordanian Election System" aimed to shed light on the quota system and to identify opinions and approaches of Jordanian women towards quota. The study concluded that the quota is a necessity for women's improvement in the society and to ensure their participation in making political decisions as tentative and gradual process which will be terminated when the situation has changed in favor of women's participation.

The study of Alkhozai (2012) "Women's Quota Barriers towards Women's Election in the Parliamentary Elections, a social filed study," aimed at identifying obstacles facing women's quota in motivating voters to elect women in the parliamentary elections and identifying the extent of participation of Jordanian women in the parliamentary elections. The study concluded that a quarter of candidates do not support the women's quota and three quarters, are in favor of the quota, calling for performing more efforts to change it for the better. 
The study of Dudley and Gitelson (2002). "Political Literacy, Civic Education and Civic Engagement: A Return to Political Socialization" emphasized the importance of political knowledge as a requirement to civic participation and political engagement but it considered that this knowledge is not always enough to participate in the civic life. For example political knowledge about the Congress might not be very useful to the citizen in an issue related to local governments. Each subject requires special related knowledge.

\section{Jordanian Women in the State's Authorities}

The year (1970) can be considered the starting point for the participation of Jordanian women in public office, when Mrs. Loris Ahlas was appointed vice permanent delegate for Jordan's mission to the United Nations, followed by women getting their right to participate in the nomination and election to the House of Representatives and municipal councils in (1974).

In the year (1978), three women were appointed in the National Advisory Council formed in the period (1978-1982) as a compensation for freezing the constitutional parliamentary life and so women were given the opportunity to participate in an activity of a legislative nature. This shaped the beginning for further women's participation. In (1980), four women were appointed in the National Advisory Council, as well as four women in (1982).

Regarding women's participation in the executive authority, it goes back to the year (1979), when Mrs. Inam Mufti was appointed Minister of Social Development. In (1984) Mrs. Leila Sharaf was appointed Minister of Information, then Dr. Rima Khalaf was appointed Minister of Industry and Commerce in (1993). Dr. Rima Khalaf was appointed Minister of Planning and Mrs. Salwa Al Masri was appointed Minister of Social Development in (1994).

In the period (1996-2000) Dr. Rima Khalaf kept her portfolio in the executive authority as Minister of Planning until she resigned at the beginning of March, (2000); Tamam Al Ghoul was appointed Minister of Social Development in (2000) and she maintained her portfolio until (2002) when Ruwaida Ma'ayteh held this portfolio after a cabinet's amendment during (2002). The Number of women in government elevated in (2003) up to four women ministers, where Alia Hatog Buran was appointed Minister of Tourism and Antiquities; Asma Khader was appointed Minister of State-Government Spokesman and Minister of Culture; Nadia Al-Saeed was appointed Minister of Communications and Information Technology; and finally Amal Farhan was appointed Minister of Municipal and Rural Affairs. (DJCM, 2000-2013).

The number of ministries given to women rose to six ministries in (2005), where Alia Hatog Buran was appointed Minister of Environment and Tourism; Asma Khader was appointed Minister of State; Nadia Sa'eed was appointed Minister of Communications; Suhair AlAli Minister of Planning and International Cooperation; and Ruwaida Ma'ayteh Minister for Social Development. In (2005), another government was formed including one woman minister who was Suhair Al Ali Minister of Planning and International Cooperation.

The number of women ministers rose again to four in (2007) where Suhair Al-Ali continued as Minister of Planning and International Cooperation; Maha Khatib was appointed Minister of Tourism; Hala Bseiso Lattouf was appointed Minister of Social Development; and Nancy Bakeer was appointed Minister of Culture.

The number of women ministers decreased in the government formed in (2009), where Hala Bseiso Lattouf retained the portfolio of Social Development and Women's Affairs; Rabha Dabbas was appointed Minister of Municipal Affairs; and Nisreen Barakat was appointed Minister for Development of the Public Sector. In the year (2011) Haifa Abu Ghazaleh was appointed Minister of Tourism and Antiquities; Salwa Al Damen Al Masri was appointed Minister of Social Development. There was no ministerial portfolio for women in the government formed in (2012), but there was a cabinet's amendment in (2013) where Reem Abu Hassan was appointed Minister of Social Development and then another amendment and Lana Mohammed Mamkagh was appointed Minister of Culture; and Lina Shabib was appointed Minister of Transportation.

Accordingly, we note that Jordanian women reached the post of deputy prime minister and they were entrusted different portfolios such as Ministry of Planning and International Cooperation, Ministry of Culture, Ministry of Social Development, Ministry of Communications and Information Technology, Ministry of Tourism and Antiquities, Ministry of Environment, Ministry of Transport and Ministry of Municipalities.

However, women were not entrusted with portfolios for key ministries such as Ministry of Foreign Affairs, Ministry of Interior, Ministry of Finance and Ministry of Justice.

With regard to women's participation in the legislative authority, (12) women were nominated for the parliamentary elections in (1989) but no one won. In the (1993) elections (3) women participated, only one, Mrs. Toujan Al Faisal won. Al Faisal ran for the Chechens and Circassians (Sharkas) seat. In the parliamentary elections of (1997), (17) women candidates participated but the surprise was the loss of Mrs. Al Faisal of her seat and the failure of all other women candidates, despite the outstanding presence registered by Toujan Al Faisal experience, local and international support of women's political participation and the interest shown by civil society 
organizations in general and women's organizations in particular to support women's nominations.

In (2003), under the Provisional Electoral law no. (34) of (2001), amended in (2003) to provide for the allocation of additional quota of seats to women, by six seats, equivalent to $(5.5 \%)$ of the total seats in the Council of (110) seats. Elections for the 14th Parliament were held, (54) women were nominated for these elections distributed in (27) electoral districts, out of (534) candidates, i.e., (10.1\%) of the total number of candidates. Competition on women's quota seats was above the national average for competition, as an average of nine candidates competed for each seat of quota's seats, compared to $(7.4 \%)$ for each seat at the national level (El Kharouf and Al Hosain, 2013; Jribia, 2004).

The year (2007) witnessed municipal and parliamentary elections in one year. (199) women candidates ran for the parliamentary elections of the total (885) male and female candidates. Women's nominations covered all districts. Elections ended with the win of (7) women candidates, one of them, Falak Jam'ani, by direct competition and six women through quota (El Kharouf and Al Hosain, 2010; Jribia, 2004).

The year (2010) also witnessed parliamentary elections on the basis of the electoral law of (2010), which includes increasing women's quota to (12) seats in the House of Representatives, a seat for each province in addition to the seats won by direct competition. Women's nominations covered all districts (MI, 2010). The elections ended with the winning of (13) women candidates, one of them, Reem Badran, through direct competition and (12) through women's quota.

The (2013) parliamentary elections were held for the 17th. House of Representatives in (23/01/2013) according to the electoral law to the House of Representatives for the year (2012) where the law witnessed a rise in the number of parliamentary seats from (120) to (150) seats. Number of seats allocated to national lists was (27) seats.

Women's quota was increased by three seats reserved for Bedouin areas and therefore the number of seats held by women in parliament became (15) seats through the quota.

The voter was given the right to cast two votes (a voice for of the local district and another for the National list).

In the (2013) parliamentary elections, women's nominations covered all districts. The elections ended with the win of (18) women candidates out of the (150) seats, with $(12 \%)$ of the seats in the 17 th parliament. Two women, Mariam Al Lozi and Wafa Bani Mustafa, won through direct competition; one woman, Rula Al Hroub, won through the National List and (15) women through women's quota. It is the highest percentage in the history of women's political participation in Jordan as women's representation in the 16th. House of
Representatives was $(10.83 \%)$ and in the 15 th. House of Representatives $(6.36 \%)$ and in the 14th. House of Representatives $(5.5 \%)$.

Regarding women's participation in the Senate, the other wing of the Jordanian National Assembly, which the King appoints its members, numbering no more than half of the members of the House of Representatives, between (40-75 members) and since the return of parliamentary life in (1989) one woman was appointed to its membership. In (1993) two women were appointed, three women in (1997) and three women in (2001). The number of women Senators increased to seven in (2003) and remained seven for the years $(2005,2007$ and 2009). The number rose to nine in (2010) and then decreased to (7) women Senators in (2011) to rise again to (9) in (2013), which is an indication of the leadership political desire to support women's political participation (DJS, 2000-2013).

At the level of women's participation in municipal councils, there was no participation until (1995) where (99) women were appointed in the municipal committees to prepare for elections in one day for the first time in all the municipalities of the kingdom. That appointment came in response to an initiative of Princess Basma Bint Talal and thus the road was paved for women to participate directly in municipal councils, which encouraged them to participate in the municipal elections of (1995) with twenty candidates, (9) among them won. Miss Eman Fteimat won the position of mayor and then the minister's cabinet appointed nineteen women in the municipal councils.

The year (2007) witnessed municipal and parliamentary elections in one year. The municipal elections were held on the basis of Law no. (14) of (2007) which includes granting women a share of seats in the municipal councils, not less than $(20 \%)$ of the number of seats, in addition to the seats won by women candidates through direct competition. The number of candidates for these elections was (380) women out of (2070) male and female candidates (El Kharouf and Al Nabulsi, 2011).

About (211) candidates won through the quota and (20) women candidates won through free competition, resulting in a total of (231) women members in different municipal councils (El Kharouf and Al Nabulsi, 2011).

Women achieved satisfactory results in the municipal elections of (2013) obtaining (29\%) of the seats. They managed to get (56) seats through direct competition and (270) on women's quota. At this rate, Jordanian women are close to $(30 \%)$ of the seats in municipal councils in the Kingdom. This figure is proof that women's role in municipal councils is characterized by efficiency and capability, as well as being realistic.

Success in elections also indicates an outstanding performance and clear fingerprints left by a number of 
women members of earlier municipal councils. These elections are characterized by some women candidates obtaining the highest number of votes which demonstrates people's conviction of women's ability to carry out public work and development work in political and social fields.

It should be noted here that the share of women in municipalities was increased after recent amendment of the municipal law regarding raising women's quota from $(20 \%)$ to $(25 \%)$ which opened the door for women to reap additional competitive seats.

The number of elected members of municipal councils and the Greater Amman Municipality is (1124) members, including (100) mayors and quota seats amounting to (270) seats, which refers to the society's strong confidence in women's role in municipal councils and local governance.

At the level of women's participation in the judiciary, the first woman to be appointed as a judge was Mrs. Tagreed Hikmat in (1996), followed by the appointment of two women. The number reached (250) women judges in (2012).

\section{Women's Quota}

The general parliamentary elections of (1989) formed the first milestone in the history of the Jordanian Parliament in which Jordanian women participated as candidates and voters and thus women fought their first experience of electoral competition for seats in the House of Representatives. Although the number of females in the ballot approached the number of males, the number of women candidates was limited to (12) women, none of them won, however, Jordanian women did not lose hope of winning in the next rounds, especially as the number of women candidates had experienced an increase.

The electoral law was amended in (1993), from the open-list system to the one-vote system (the majoritarian, first-pass-the-post system) to weaken women's opportunity to access the parliament and increasing the chances of men who enjoy the support of the tribe and that led to women's weak participation through competition, compared with the (1989) elections, the number of women candidates was three ladies only and the surprise was the winning of Mrs. Toujan Al Faisal, who won the seat allocated to the Chechens and Circassians (Sharkas) in the third district of the capital, Amman and thus benefited from the quota system allocated for minorities. The performance of Mrs. Al Faisal in the House of Representatives was bold which draw attention to her and raised hopes that women are capable of proving themselves in electoral and parliamentary arenas.

In the (1997) elections, which took place under a wide boycott by political parties and independent figures, women's wide participation was noted in nomination and participation, where (17) women ran for elections. An increasing interest of civil society organizations, women's bodies and research centers in supporting women nominations and their campaigns was noted. The Jordanian National Forum for Women, chaired by Princess Basma Bint Talal, was active in this domain where it nominated a number of its members for elections. The Jordanian National Commission for Women initiated to support women candidates and cover their election campaign on TV. There was a belief that women's chances of winning the election were great and that they enjoyed great popular and formal acceptance and that the opportunity became favorable for the arrival of more than a woman to the Parliament, but results were disappointing, none of the women candidates won and even the one and only Mrs. Al Faisal lost her seat in Parliament.

These results pointed out great difficulties that stand in the way of enhancing women's political participation, especially at the level of the House of Representatives with a reasonable number of seats. In fact, there were social and political forces which were aware of the existence of these difficulties due to a culture governed by patriarchal norms, as well as recognizing the Palace's positive attitude towards women's political participation manifested by appointing a number of women in the government and in the Senate which was not enough to generate a fundamental shift in public opinion in favor of women's representation in the House of Representatives and in particular that the electoral law system of one vote did not provide a suitable ground for it (Jribia, 2004).

Table 1. Percentages of women's political participation in various locations for the years (1990-2013)

\begin{tabular}{|c|c|c|c|c|c|c|c|c|c|c|c|}
\hline Period & 1990 & 1995 & 2000 & 2005 & 2006 & 2007 & 2008 & 2009 & 2010 & 2011 & 2013 \\
\hline $\begin{array}{l}\text { Percentage of women's participation } \\
\text { in the first Legislative Council (Senates) }\end{array}$ & 2.6 & 5.3 & 8.0 & 12.1 & 12.1 & 12.7 & 12.7 & 10.9 & 15.0 & 11.7 & 13.0 \\
\hline $\begin{array}{l}\text { Percentage of women's participation in } \\
\text { the Second Legislative Council } \\
\text { (House of Representatives) }\end{array}$ & 0.0 & 1.3 & 0.0 & 5.8 & 5.8 & 6.4 & 6.4 & 6.4 & 10.8 & 10.8 & 12.0 \\
\hline $\begin{array}{l}\text { Percentage of women members } \\
\text { in Municipal Councils }\end{array}$ & N/A & 0.5 & 4.4 & 10.0 & 10.0 & 27.8 & 27.4 & 27.4 & 24.8 & 24.8 & 24.8 \\
\hline $\begin{array}{l}\text { Percentage of women in } \\
\text { government at the Ministerial level }\end{array}$ & 4.8 & 0.0 & 3.4 & 10.5 & 3.8 & 14.8 & 14.3 & 14.3 & 9.7 & 4.5 & 12.3 \\
\hline
\end{tabular}

Source: (DOS, Database 1993-2013) 
Therefore, the pivotal powers in the community realized that there is no substitute for a quota of seats for women in parliament, at least for a transitional period, because it opens the way for women's broad participation in the nomination for the House of Representatives and ensures equal opportunities for women to compete in the elections on the basis of direct competition, allowing the election of the best and most efficient candidates and devoting women's presence in parliament and that is what this case study is trying to monitor in order to determine the extent of the progress of a model of quality initiatives, led by some forces or civil society institutions in Jordan.

\section{Development of Women's Quota Idea}

A close look at table 1 shows that percentages of women's political participation increased during the period (1990-2013) but that increase did not meet the desired expectations aimed at empowering Jordanian women.

The first initiatives aimed at highlighting the importance of allocating a share of the House of Representatives seats for women (women's quota), was a seminar held by New Jordan Research Center for studies in collaboration with the Royal Cultural Center on the eve of the parliamentary elections of (1993), titled: "Jordanian Women and Political Action" in July (1993).

The seminar discussed, in depth, the reality of the Jordanian women's movement and obstacles to promote women's participation in politics and the public sphere, especially women's participation in elections and their chances of access to parliament and other decision-making centers. It revealed a modest support for women's quota, while parties opposed to the quota focused on the importance for women to prove themselves through free and direct competition and not to be treated as minorities as long as women constitute half of the society. They also focused that women's quota will add a new negative point to an electoral law, already full of drawbacks.

In June (1995) The New Jordan Research Center for Studies held another seminar on: "The Election Legislation... Cornerstone of the Democratic System." In preparation for this seminar, the Center's researchers conducted a survey on attitudes of Jordanian political parties towards the electoral law and proposals to modify it. The survey's results, answered by (20) parties out of (23) parties, which existed at that time, showed that only five parties supported a women's quota in parliament with the percentage of $(25-10 \%)$ of the total number of seats, while (13) parties opposed it, suggesting that the search for practical solutions to ensure the political participation of women was not a priority for most parties, which care to attract women in order to support their candidates for the elections.

However, the seminar referred to, paid special attention to discuss ways of securing women's access to parliament and confirmed in the final statement, issued by participants' consensus, on the need to support women and enhance their role in the political life and parliamentary involvement and the search for appropriate mechanisms for that.

In February (1996) expectations were high regarding the possibility of amendments of the electoral law with the government formed by Mr. Abdel Karim Al Kabariti, that adopted a positive attitude towards women's quota and leaked to the press a new draft law for election without identifying its source, allocating (17) seats for women and raising the number of seats in the House of Representatives from (80) to (100) seats, which revived national dialogues about women's representation, even though the government did not adopt this project.

New Jordan Research Center initiated a seminar on "Women and the Jordanian Electoral Law," in commemoration of International Women's Day, in March (1998), with wide participation of leaders and representatives of women's organizations.

Presentations and papers were presented at this seminar reviewing the experience of female representation in a large number of world's parliaments and showing the importance of "positive discrimination" in favor of women stipulated by the Convention on the Elimination of Discrimination against Women.

The discussions' atmosphere reflected a growing support for women's quota, especially that the seminar heard a number of testimonies of women and men who supported women's quota as an irreplaceable temporary solution to ensure proper representation of women, where they had opposed it before. The seminar concluded with its round table which aimed at reaching an action plan to support women's access to parliament. The table resulted in the formation of a committee tasked to develop a work plan and appropriate mechanisms for its implementation. In the light of the round table recommendations of the of Jordanian Women and the Electoral Law, the so-called "Women's Alliance" was formed in mid (1996) of representatives of nongovernmental bodies, women's associations, civil society organizations concerned with women and independent female figures in order to coordinate efforts and form a pressure group to discuss ways and mechanisms to increase and develop a correct and fair participation for Jordanian women in the upcoming elections.

The alliance began its activity by inviting other bodies and female characters for consultation and approval of the program of action which adopted a claim to allocate $(20 \%)$ of the seats in parliament for women and to address decision-makers in the legislative and executive powers and then to prepare to meet the King. A meeting took place with heads of the House of Representatives and the Senate who showed willingness to cooperate, but asked for further clarification of the concept of quota and specific proposals for 
implementation. The alliance's memorandum was also handed over to the Prime Minister.

The alliance held at that time a series of meetings in which many unions, women's organizations and independent personalities participated in early stages. The alliance also addressed parties responsible for requesting funding for its activities.

A Committee was formed of heads of women's associations to meet the Prime Minister for this purpose, but the committee did not do what was required.

This was followed by manifested "differences" among the women's movement on the location of the "Women's Alliance" and its place in particular that "the Alliance" did not represent a licensed legal framework, which led to intervention of some government parties that did not have a positive outlook towards its movement, which paralyzed the Women's Alliance and froze its activities leading to its end.

During that time, women's arena experienced another path which contributed to raising awareness of the importance of promoting women's political participation, by resorting to the appointment of a large number of women in municipal committees, on the eve of municipal elections of (1995) which took place in all the municipalities in a single day for the first time. Through Princess Basma's initiative, local authorities agreed on appointing (99) women within the total municipal committees formed for the purpose of configuration of municipal elections and their presidents.

This move came in the context of increasing local interest in women's issues during Beijing conference and Princess Basma's initiative to create women's forum under the name "Jordanian National Forum for Women" which covered all governorates of the Kingdom.

In this atmosphere twenty women ran for the municipal elections that took place in July (1995). One woman won presidency of one of these municipalities, while nine others won membership in a number of municipal councils.

Since the municipal law entitled the council of ministers to appoint two additional members to elected municipal councils, the council responded to Princess Basma's request to appoint (23) women in a number of municipal councils.

This practical experience encouraged more women to run as candidates in the municipal elections held in July (1999) where the number of candidates reached (43) women, but only (8) women won membership of the councils (DMMJ, 1995-2013).

As a result of all the above, it can be said that the idea of allocating a certain percentage of seats in the House of Representatives for direct competition among women candidates gained new supporters. The number of bodies and women's associations that adopted the idea increased and the idea became part of their work program. It was also noted that the issue of women's quota became a major theme raised in all seminars and meetings that researched women's issues or the electoral law.

The results of two opinion polls on the subject of women's quota can be used as witness: The first organized by Center for Jordanian Studies at Yarmouk University in October (1997) on a national sample of (2811) individuals, in order to identify individuals' attitudes towards the parliamentary elections of (1997) and the extent of their agreement on the existence of a quota for women. It demonstrated that $(45.4 \%)$ of the respondents supported the allocation of quota for women, while $(44.1 \%)$ of them were opposed. The second conducted by Al Arab Al Yawm newspaper in July (1999). It demonstrated that $(62.7 \%)$ of the respondents supported the allocation of quota for women for an interim period.

Although these numbers seemed a bit high, they, at least, reflected a growing support for women's quota as an input to overcome obstacles facing women's parliamentary representation, even for a specified period of time so that women's presence in Parliament became a reality accepted by the Jordanian society.

A national body was formed under the guidance of King Abdullah II Ibn Al Hussein to develop the document "Jordan first" and it was issued on (30/10/2002) and called for achieving social consensus among Jordanians, males and females, individuals and groups and the need to take into account women's empowerment to participate as voters and candidates and to ensure women's arrival to parliament through Women's quota, to be temporary (MI, 2002).

In February (2003) the Provisional law no. (11) for the year (2003) was issued and under Article (24), paragraph (c) six seats were allocated for women in the House of Representatives (MI, 2003).

In (2010) an amendment to the electoral law was issued under which the number of seats for women's quota was doubled to become under the current law (12) seats (MI, 2010).

Another amendment was also issued in (2012) to add (3) seats for Bedouins under the current law raising women's quota to (15) seats, which increased the chance of participation of Jordanian women to win elections, activate their role to participate in the actual decisionmaking development and establish themselves in social, developmental and political movement.

\section{Quota Means}

The Share and politically means providing an opportunity for the underprivileged in the society on the basis of (minorities, sex, religion, geographical areas) to get, through elections, to representative institutions (Parliament, municipalities) (UNIFEM, 2008). 
In Jordan's Mixed Electoral System, (108) members are elected from (45) single or multi-member districts, (15) seats are reserved for women from (12) governorates and (3) Bedouin districts (as part of the 2012 electoral law reform) and (27) members are elected through a proportional representation system. In single or multi-member district elections, men or women with highest vote totals within their districts are declared elected. Women running for reserved seats do not campaign for these seats separately, but rather run in their districts as part of the constituency seat elections. In each governorate or the Bedouin district, the female candidate who garners the highest proportion of the vote in their district but without being elected outright is awarded the seat reserved for women.

\section{Motives of Women's Participation in Elections}

Results of field studies (El Kharouf and Al Khozai, 2013; Rabie, 2012) indicated that the motives of women's participation in elections were:

- The desire to prove oneself: Women seek to establish themselves in the community, especially after they got opportunities for education and employment. This was accompanied by transformation in the society's structure and nature, which formed a strong motivation for women's participation in elections

- Jordanian women's response to women's sector movement in Jordan in general: Women's attendance and participation in organizations or women's bodies working on the national level registered a significant presence increasing women's awareness of the importance of their role and their self-confidence

- Amendments in the electoral laws: Including the allocation of a number of seats for women (women's quota), which formed a motive for women after they saw that these changes allow them an opportunity to participate in the elections

- To achieve a personal ambition: Where many women possess personal ambitions to access power which is a human nature existing in women and men
- Change in the society's thinking pattern: Recent years witnessed changes in society's thinking patterns as a result of education and openness to other societies which contributed to changing the thinking pattern of men and women alike and contributed to the promotion of women's participation. A group of men emerged supporting women and demanding their participation in elections

\section{Reality of Women's Participation in Parliamentary Elections}

A close look at Table 2 shows the rapid development in women's representation in the House of Representatives, rising from (1.3\%) in (1993) with one woman, to (12.0\%) in (2013) with eighteen women, (15) women through women's quota, one woman through the National List and two women won through direct competition (DoS, Database 1993-2013).

This finding indicates women's awareness of the importance of women's participation in political life, activating their role in the actual decision-making in development and establishing themselves in social, developmental and political movement. On the other hand it refers to a change in the community's approach towards different roles that can be carried out by women and their participation in the development process in all areas.

Table $3 \mathrm{a}$ and $3 \mathrm{~b}$ Shows women deputies per their distribution in different provinces and the method of their success (competition or quota), which confirms the success of precedent women deputies in doing their regulatory and legislative role which reflected significantly on voters' choices males and females. Precedent women deputies formed in the (2012) election $(44.4 \%)$ of the total winner candidates and that $(11.1 \%)$ of them possessed doubled parliamentary expertise, all of which indicated the importance of the presence of precedent women deputies as well as efficient and experienced women under the parliament's dome, in order to continue making a difference, preventing discrimination and guaranteeing gender equality.

Table 2.Distribution of women deputies at the house of representatives (Majless-annowab) by their presence for the years (1993-2013)

\begin{tabular}{llllll}
\hline No. of women elected to national lists/election year & 1993 & 2003 & 2007 & 2010 & 2012 \\
\hline No. of women elected by direct competition & 1 & - & 1 & 1 & 2 \\
No. of seats reserved for women (quota) & No gender quotas & 6 & 6 & 12 & 15 \\
No. of women elected in Majless-annowab & 1 & 6 & 7 & 13 & 18 \\
Total Number of women elected in Majless-annowab & $1.3 \%$ & $5.5 \%$ & $6.4 \%$ & $10.8 \%$ & $12.0 \%$ \\
& Out of (80) & Out of (110) & Out of (110) & Out of (120) & Out of (150) \\
\hline
\end{tabular}

Source: (DOS, Database 1993-2013) 
Table 3a. Distribution of Successful Women Deputies by direct election, Quota, or National List in the House of Representatives for the years (1993-2013)

\begin{tabular}{|c|c|c|c|c|}
\hline $\begin{array}{l}\text { Election } \\
\text { year }\end{array}$ & Name & $\begin{array}{l}\text { Government } \\
\text { Representation }\end{array}$ & & $\begin{array}{l}\text { Parliamentary experience (seat } \\
\text { awarded through quota or direct election) }\end{array}$ \\
\hline 1993 & Toujan Al Faisal & Amman (Sharkas) & & No \\
\hline \multirow[t]{6}{*}{2003} & Adab Mubarak Saleh Al S'oud & & Quota & No \\
\hline & Hayat Hussein Ali Mseimi & & Quota & No \\
\hline & Insaf Ahmad Salam Khawaldeh & Tafileh & Quota & No \\
\hline & Zakiyeh Mohammed Suleiman Al Shamayleh & & Quota & No \\
\hline & Falak Suleiman Mubarak Al Jamaani & Madaba & Quota & No \\
\hline & Nariman Zuheir Ahmad Al Rousan & Irbid & Quota & No \\
\hline \multirow[t]{7}{*}{2007} & Falak Suleiman Mubarak Al Jamaani & Madaba & & Elected in Madaba region in 2003 \\
\hline & Insaf Ahmad Salam Khawaldeh & Tafileh & Quota & Elected in Tafileh region in 2003 \\
\hline & Hamdiyeh Nawwaf Fares Al Queider & Karak & Quota & No \\
\hline & Reem Ahmad Kasem Abdul Razsak & Zarqa & Quota & No \\
\hline & Tharwat Salameh Mohammed Al Amro & Karak & Quota & No \\
\hline & Nariman Zuheir Ahmad Al Rousan & Irbid & Quota & Elected in Irbid region in 2003 \\
\hline & Amneh Suleiman Abdullah Al Fawaeer & Balqa & Quota & No \\
\hline
\end{tabular}
Source: (DOS, Database 1993-2013)

Table 3b. Distribution of Successful Women Deputies by direct election, Quota, or National List in the House of Representatives for the years (1993-2013)

\begin{tabular}{|c|c|c|c|c|}
\hline $\begin{array}{l}\text { Election } \\
\text { year }\end{array}$ & Name & $\begin{array}{l}\text { Government } \\
\text { representation }\end{array}$ & & $\begin{array}{l}\text { Parliamentary experience (seat } \\
\text { through quota or direct election) }\end{array}$ \\
\hline & Reem Modar Badran & Amman & & No \\
\hline & Nariman Zuheir Ahmad Al Rousan & Irbid & Quota & Elected in Irbid region in 2003, 2007 \\
\hline & Asma Al Rawadieh & Ma'an & Quota & No \\
\hline & Huda Abu Rumman & Balqa & Quota & No \\
\hline & Kholoud Al Marahleh & Karak & Quota & No \\
\hline & Rudaina Mahmoud Al Atti & Zarqa & Quota & No \\
\hline \multirow[t]{16}{*}{2010} & Wafaa Bani Mustafa & Jarash & Quota & No \\
\hline & Amal Al Rfou' & Tafileh & Quota & No \\
\hline & Salma Al Rabadi & Ajloun & Quota & No \\
\hline & Abla Abu Olbeh & Amman & Quota & No \\
\hline & Samia Al Oleimat & Mafraq & Quota & No \\
\hline & Miassar Sardiyeh & North Badia & Quota & No \\
\hline & Tamam Riyati & Aqaba & Quota & No \\
\hline & Mariam Mohammed Musa Lozi & Amman & & No \\
\hline & Wafaa Bani Mustafa & Jarash & & Elected in Jarash region in 2010 \\
\hline & Rula Hroub & Amman & Quota & No \\
\hline & Naayem Salameh Yousuf Eiadat & Amman & Quota & No \\
\hline & Hamdiyah Nawwaf Faris Al Qweider & Karak & Quota & \\
\hline & Fatima Ali Deif Allah Abu Abteh & Irbid & Quota & Elected in Balqa regio in 20132007 \\
\hline & Amneh Suleiman Abdullah Al Fawaeer & Balqa & Quota & No \\
\hline & Faten Atallah Abullah Al Khleifat & Ma'an & Quota & No \\
\hline & Rudaina Al Atti & Zarqa & Quota & Elected in Zarqa region in 2010 \\
\hline \multirow[t]{9}{*}{2013} & Reem Oklah Nawash Abu Dalbouh & Mafraq & Quota & No \\
\hline & Insaf Ahmad Salam Khawaldeh & Tafileh & Quota & $\begin{array}{l}\text { Elected in Tafileh region } \\
\text { in } 2003,2007\end{array}$ \\
\hline & Falak Suleiman Mubarak Al Jamaani & Madaba & Quota & $\begin{array}{l}\text { Elected in Madaba region } \\
\text { in } 2003,2007\end{array}$ \\
\hline & Najah Mohammed Muslim Al Azzeh & Jarash & Quota & No \\
\hline & Kholoud Mohammed Abdullah Khatatbeh & Ajloun & Quota & No \\
\hline & Tamam Riyati & Aqaba & Quota & Elected in Aqaba region in 2007 \\
\hline & Miassar Sardiyeh & North Badia & Quota & Elected in North Badia in 2010 \\
\hline & Hind Hakem Sultan Al Fayez & Mid Badia & Quota & No \\
\hline & Shaha Salem Salim Abu Shosheh & South Badia & Quota & No \\
\hline
\end{tabular}

Source: DJHR, 2000-2013. Database of the Jordanian house of representatives. Amman, Jordan

With regard to the effectiveness of women deputies in successive councils, we find, through the previous table, a positive change in participation in decision-making, as it demonstrates that a higher percentage of women have become involved as reporters of committees in the current
House of Representatives (Legal Committee, Financial Committee, Committee of Education and Culture, the Committee of Agriculture and Water, the Committee of Labor and Social Development and Population, Committee of Tourism and Antiquities and Committee of 
Women's Affairs), after being reporters of only the Committee of Education, Culture and Youth in the House of Representatives in (2007) and in committees of
(Education, Culture and Youth, National Directions Committee and the Committee of Labor and Social Development) in (2010).

Table 4a. Distribution of women deputies in various committees in the House of Representatives for the years (1993-2013)

\begin{tabular}{|c|c|c|c|c|c|c|}
\hline \multirow[b]{2}{*}{$\begin{array}{l}\text { Election } \\
\text { year }\end{array}$} & \multirow[b]{2}{*}{ Committee } & \multicolumn{3}{|c|}{ Deputy's Position } & \multicolumn{2}{|c|}{ Members } \\
\hline & & $\begin{array}{l}\text { Chairman of } \\
\text { committee }\end{array}$ & $\begin{array}{l}\text { Vice-c } \\
\text { chairman }\end{array}$ & $\begin{array}{l}\text { Reporter of } \\
\text { committee }\end{array}$ & Male & Female \\
\hline \multirow[t]{15}{*}{2007} & Committee on Address to the Throne & Male & - & Male & 13 & 1 \\
\hline & Legal Committee & Male & - & Male & 9 & - \\
\hline & Financial and Economic Committee & Male & - & Male & 9 & - \\
\hline & Committee of Arabic and International Affairs & Male & - & Male & 9 & - \\
\hline & Administrative Committee & Male & - & Male & 9 & - \\
\hline & Committee of Education, Culture and Youth & Male & - & Male & 8 & 1 \\
\hline & Committee of National Directions & Male & - & Female & 9 & - \\
\hline & Committee of Health and Environment & Male & - & Male & 9 & - \\
\hline & Committee of Agriculture and Water & Male & - & Male & 8 & 1 \\
\hline & Labor and Social Development Committee & Male & - & Male & 7 & 2 \\
\hline & Committee of Energy and Mineral Treasure & Male & - & Male & 9 & - \\
\hline & Committee of Public Services and Tourism and Antiquities & Male & - & Male & 7 & 2 \\
\hline & Committee of Public Freedom and Rights of Citizens & Male & - & Male & 9 & - \\
\hline & Committee of Palestine & Male & - & Male & 9 & - \\
\hline & Committee of Rural and Desert Areas & Male & - & Male & 7 & - \\
\hline \multirow[t]{16}{*}{2010} & House Speaker' Assistant & & - & & 1 & 1 \\
\hline & Committee on Address to the Throne & & - & & 14 & 2 \\
\hline & Legal Committee & Male & - & Male & 8 & 1 \\
\hline & Financial and Economic Committee & Male & - & Male & 8 & 1 \\
\hline & Committee of Arabic and International Affairs & Male & - & Male & 8 & 1 \\
\hline & Administrative Committee & Male & - & Male & 9 & - \\
\hline & Committee of Education, Culture and Youth & Male & - & Female & 8 & 1 \\
\hline & Committee of National Directions & Male & - & Female & 8 & 1 \\
\hline & Committee of Health and Environment & Male & - & Male & 9 & - \\
\hline & Committee of Agriculture and Water & Male & - & Male & 8 & 1 \\
\hline & Labor and Social Development Committee & Male & - & Female & 7 & 2 \\
\hline & Committee of Energy and Mineral Treasure & Male & - & Male & 8 & 1 \\
\hline & Committee of Public Services and Tourism and Antiquities & Male & - & Male & 9 & - \\
\hline & Committee of Public Freedom and Rights of Citizens & Female & - & Male & 8 & 1 \\
\hline & Committee of Palestine & Male & - & Male & 6 & 3 \\
\hline & Committee of Rural and Desert Areas & Male & - & Male & 8 & 1 \\
\hline
\end{tabular}

Source: DJHR, 2000-2013. Database of the Jordanian house of representatives. Amman, Jordan.

Table 4b. Distribution of women deputies in various committees in the House of Representatives for the years (1993-2013)

\begin{tabular}{|c|c|c|c|c|c|c|}
\hline $\begin{array}{l}\text { Election } \\
\text { Year }\end{array}$ & Committee & $\begin{array}{l}\text { Deputy's Position } \\
\text { Chairman of } \\
\text { Committee }\end{array}$ & $\begin{array}{l}\text { Members } \\
\text { Vice-c } \\
\text { chairman }\end{array}$ & $\begin{array}{l}\text { Reporter of } \\
\text { Committee }\end{array}$ & Male & Female \\
\hline \multirow[t]{20}{*}{2012} & Legal Committee & Male & Male & Female & 8 & - \\
\hline & Financial and Economic Committee & Male & Male & Female & 8 & - \\
\hline & Committee for Economy and Investment & Male & Male & Male & 8 & - \\
\hline & Foreign Affairs Committee & Male & Male & Male & 8 & - \\
\hline & Administrative Committee & Male & Male & Male & 8 & - \\
\hline & Committee of Education and Culture & Male & Male & Female & 6 & 2 \\
\hline & Committee of Youth and Sports & Male & Male & Male & 8 & - \\
\hline & Committee of National Directions and Media & Male & Male & Male & 7 & 1 \\
\hline & Committee of Health and Environment & Male & Male & Male & 8 & - \\
\hline & Committee of Agriculture and Water & Male & Male & Female & 8 & - \\
\hline & Committee of Labor, Social Development and Population & Male & Male & Female & 7 & 1 \\
\hline & Committee of Energy and Mineral Treasure & Male & Male & Male & 8 & - \\
\hline & Committee of Public Services and Transportation & Male & Male & Male & 8 & - \\
\hline & Committee of Tourism and Antiquities & Male & Male & Female & 7 & 1 \\
\hline & Committee of Public Freedom and Rights of Citizens & Female & Male & Male & 8 & - \\
\hline & Committee of Palestine & Male & Male & Male & 7 & 1 \\
\hline & Committee of Rural and Desert Areas & Male & Male & Male & 7 & 1 \\
\hline & Committee of Rules and Conduct & Female & Male & Male & 7 & 1 \\
\hline & Committee for Transparency, Integrity and Investigation. & Male & Female & Male & 8 & - \\
\hline & Committee of Women and Family Affairs & Female & Female & Female & 2 & 6 \\
\hline
\end{tabular}

Source: DJHR, 2000-2013. Database of the Jordanian house of representatives. Amman, Jordan. 
It is also noted that women headed various committees such as (Public Freedoms and Human Rights Committee, the Committee of Rules and Conduct and the Committee of Women and Family Affairs), or became vice-president of committees (such as the Committee for Transparency, Integrity and Investigation and the Committee of Women and Family Affairs), in addition to their membership in a variety of other committees (Table 4a and 4b).

On the other hand, we find that a new committee was formed for women and women's affairs in the current House of Representatives which did not exist in the past, which shows the interest of the House of Representatives in women's affairs and an increase in their confidence in women's role in Parliament and in the society's development.

\section{Factors Affecting Women's Winning or Losing in Elections}

Women's access to positions of power and decisionmaking and to the legislative power, in particular is no longer just a basic requirement of justice and democracy, but is also a necessary condition to the decision in order to achieve goals of equality and participation, which respond to the requirements of socio-economic development, forming the material basis of the society's progress (Nafa, 1993).

However, the phenomenon of women's limited political participation is the outcome of many interacting and overlapping factors at the community level, in general, whether political, or economic, or social or cultural and sometimes legislative. Most of the developing countries and Arab societies share these factors.

Following are the most important factors reached by results of surveys (El Kharouf and Al Alkhozai, 2013) which affect women's winning in elections.

\section{Competition and social Conflict}

Jordanian tribes give considerable attention to the issue of elections, both parliamentary and local (municipalities). The (2012) elections gained unprecedented attention from Jordanian tribes as swift action was witnessed by tribes to participate and vote in the elections and to follow a democratic approach by large tribes, to endorse a candidate who is capable and efficient for competition and successful representation of the tribe in Parliament. The tribal screening process was characterized by a democratic transparent form where tribes resorted to preliminary informal tribal elections among their sons interested in nomination, mostly males. The tribe's sons often support the candidate produced by the internal elections in the tribe and give him material support and votes that enable the candidate to win the elections.

It is noteworthy that there were women candidates for the parliamentary elections who won the tribe's consensus, despite the tribe's strict attitude towards the issue of women's participation in the elections, but some tribes have exceeded the norms, traditions and customs and when it found itself unable to compete with large tribes in elections, resorted to promote a woman candidate for the elections and support her to win a seat through the women's quota, which is in itself a victory and an unprecedented civilized step in the Arab countries to give consensus to a female candidate instead of a male candidate, as happened in the (2010) elections and the consensus given to five women candidates and the tribe contributed to their win through women's quota in the parliamentary elections, an important initiative cleverly used by women in the elections.

\section{Personal Factors Such as the Candidate's Strong Personality}

Self-confidence and enjoyment of a political culture played a role in women's winning the elections.

\section{Women's Lack of Support for Women in Parliamentary Elections}

This corresponds with the results of the parliamentary elections where a decline in the proportion of votes obtained by women candidates is observed due to women's weak confidence in women's ability to participate effectively in Parliament. Women represent half of the Jordanian society so if women voted for women in elections it would have been manifested in the elections' results.

\section{Lack of Experience}

This emerged in poor management of electoral campaigns including developing programs and activities and poor communication skills with voters. Parliamentary elections need follow up, organization and side agreements and these matters need money, expertise and continuous follow-up. Jordanian women by virtue of customs and traditions can not do this work which led to a negative impact, resulting in women's failure in the elections outside the women's quota.

\section{Financial Inability of Women Candidates}

There are very rich candidates at the same time there are women candidates of whom finances and living conditions are not likely to confront the wealthy. Economic factors played a major role in attracting voters to electoral headquarters, spending time with them, exchanging views and suggestions, offering unlimited food, beverages and dessert and distributing subsidies directly or indirectly to the poor in their electoral districts, where these candidates appointed experienced people to manage their electoral campaigns with the help of cadres to collect information and data on voters and setting programs and schedules with the voters' names 
and addresses and communicating with them through all means of personal and electronic communication and cell phones' messages.

Finally we should not forget to mention the electoral law with its pros and cons which is considered one of the factors influencing women's win in the elections.

In the end, we can say that women's win in the parliamentary elections can not be attributed to one factor, but it is due to the interaction of several factors. The most important factors that helped women win in the parliamentary elections can be summarized by the following: Allocation of seats for women (quota), tribal support was major in the presence of the quota, as well as women's participation in volunteer activities, social events private and public, which enhanced community's confidence in them, as well as woman's strong personality and self-confidence and previous experiences gained in the House of Representatives.

Regarding the factors that limit women's win in the parliamentary elections, it was shown that as the tribe played a role in women's win, the tribe also had a role in women's failure in elections if the tribe guaranteed the winning of a man of the tribe. Limited political culture in the community, especially in the field of understanding women's roles in the parliament and the stereotype of women in society also played a role, in addition to women's lack of adequate leadership skills due to lack of necessary training. Women's weak financial status also played a role in their failing in elections.

\section{Conclusion}

Jordanian women made great strides towards their appropriate roles in political life. The political will urged successive governments to work on the development of mechanisms for women's political participation. Women achieved success in terms of participation in the executive authority as they were appointed Deputy Prime Minister, Minister of Planning and International Cooperation, Minister of Culture, etc. but were not entrusted to portfolios of "sovereign" ministries.

With regard to women's participation in the legislative authority, the percentage of women's representation in the House of Representatives developed rapidly, rising from $(1.3 \%)$ in (1993) to $(12.0 \%)$ in (2013), after the electoral law was amended to grant women, women's quota. The number of members of the Senate in (2013) was nine Senators. Women won satisfactory results in the (2013) municipal elections with $(29 \%)$ of the seats. As for women's representation in the judiciary, the number of women judges in (2012) was (250) judges.

The most important factors that helped women win in the parliamentary elections were the presence of seats reserved for women (women's quota), tribal support in the presence of the quota, as well as woman's strong personality and previous experience in the House of Representatives.

Regarding the factors that limited women's winning in the parliamentary elections, the study pointed out the tribe's role in women's failure in elections when the tribe guaranteed the winning of a man from within. Society's limited political awareness, stereotypes, women's lack of sufficient leadership skills and women's poor finances were also other factors that led to women's failure in the elections.

Although Jordanian women achieved success in the political life over the past decades, hard work is still needed, at all levels, to overcome challenges standing in women's way in order to access decision-making positions by direct competition and without relying on "positive discriminatory" mechanisms.

\section{Acknowledgment}

Thanks go to the Prime Ministry, the House of Representatives and the House of Senates for facilitating access to the needed data.

We would also like to extend our thanks to Areej Abdelwahab Zgailat for assisting in data acquisition from the House of Representatives and the House of Senates.

\section{Funding Information}

The research was not funded.

\section{Author's Contributions}

All authors equally contributed in this work.

\section{Ethics}

This article is original and contains unpublished material. The corresponding author confirms that all of the other authors have read and approved the manuscript and no ethical issues involved

\section{References}

Alkhozai, H., 2012. Women's quota barriers towards women's election in the parliamentary elections, a social filed study. Jordan J. Soc. Sci.

DJCM, 2000-2013. Database of Jordanian council of ministers. Amman, Jordan.

DJHR, 2000-2013. Database of the Jordanian house of representatives. Amman, Jordan.

DJS, 2000-2013. Database of the Jordanian senate. Amman, Jordan.

DMMJ, 1995-2013. Database of the ministry of municipalities in Jordan, Amman, Jordan. 
DOS, 1993-2013. Database of the Department of Statistics. Amman, Jordan.

El Kharouf, A. and E. Al Alkhozai, 2013. Factors influencing the win of women in the parliamentary elections of 2007. Jordan J. Soc. Sci.

El Kharouf, A. and E. Al Hosain, 2010. The experience of Jordanian women candidates in parliamentary elections in 2007. Jordan J. Soc. Sci.

El Kharouf, A. and S. Al Nabulsi, 2011. Reality and needs of Jordanian women in municipal councils. Jordan J. Soc. Sci.

Eyadat, M.K., 2007. Towards political empowerment of Jordanian women, United Nations development fund for women. Amman, Jordan.

Jribia, M., 2004. Women and political participation in Jordan: Evolution of the approach towards allocating a share of parliamentary seats for women, a chapter in a book entitled: Case Studies in Civil society. The New Center of Jordan, Amman, Jordan.

Jribia, M., 2012. Women and elections in Jordanian Badia: A comparative study of parliamentary elections (2003, 2007 and 2010). Amman, Jordan.

Majeed, A., H. DKhazneh and A. El Kharouf, 2011. Political awareness and political participation of rural women in Jordan, Survey Study. Yarmouk J. Soc. Sci.
MI, 2002. Jordan first document, a report on Jordan first document. Ministry of Information, Amman, Jordan.

MI, 2003. The house of representatives election law, temporary law no. 34 for the year (2003). Ministry of the Interior, Amman, Jordan.

MI, 2010. The house of representatives election law, temporary law no. (9) for the year (2010). Ministry of the Interior, Amman, Jordan.

Nafa, E., 1993. Women in the parliamentary elections, worksheet.

Othman, A., 2004. Role of women in legislation and political issues. Proceedings of the Conference on Women and Political Development, (WPD' 04), International Institute for Women's Solidarity, Jordan.

UNIFEM, 2007a. Women and the electoral process. United Nations Development Fund for Women, Amman, Jordan.

UNIFEM, 2007b. Towards political empowerment of Bahraini women. United Nations Development Fund for Women, Amman, Jordan.

UNIFEM, 2008. Regional parliamentary studies. United Nations Development Fund for Women Publications, Amman, Jordan. 